\title{
Studies on the extraction of wheat germ oil by commercial hexane
}

\author{
By Ola. A. Megahad and Omayma S. EI Kinawy
}

Fats and Oils Dept .,NRC,Cairo, Egypt.

\begin{abstract}
RESUMEN
Estudios sobre la extracción de aceite de germen de trigo mediante hexano comercial.

Se ha estudiado la extracción de un aceite comestible a partir del germen de trigo, importante subproducto de la industria de la molienda del trigo en Egipto, usando hexano comercial. La extracción se llevó a cabo en una etapa única y en dos sucesivas, usando diferentes relaciones solvente-sólido desde 2 a $6 \mathrm{~m}^{3} /$ ton. Los resultados mostraron que una buena recuperación de aceite (alrededor del $75 \%$ ) puede alcanzarse usando $4 \mathrm{~m}^{3}$ de hexano por cada tonelada de germen extraído en una etapa única. Esta cantidad de solvente puede reducirse a 2 ' $5 \mathrm{~m}^{3} / \mathrm{ton}$ si el proceso se lleva a cabo en dos etapas sucesivas. El estudio mostró también que la cantidad de aceite recuperada a partir del germen de trigo no se afectó significativamente por el calentamiento de la mezcla durante el proceso de extracción.

También se estudió la producción de ácidos libres y peróxidos en el aceite durante el período de almacenamiento del germen de trigo anterior a la extracción y durante el proceso de extracción en caliente.
\end{abstract}

PALABRAS-CLAVE: Aceite - Extracción - Germen de trigo - Hexano.

\section{SUMMARY}

Studies on the extraction of wheat germ oil by commercial hexane.

Extraction of an edible oil from wheat germ, an important byproduct of wheat milling industry in Egypt, using commercial hexane was studied. The extraction was carried out in a single and in two successive stages using different solvent-to-solid ratios from 2 to $6 \mathrm{~m}^{3}$ / ton. The results showed that a good oil recovery (about $75 \%$ ) can be achieved using $4 \mathrm{~m}^{3}$ hexane for each ton germ extracted in a single stage. This amount of solvent can be reduced to $2.5 \mathrm{~m}^{3} /$ ton if the process is carried out in two successive stages. The study has shown also that the amount of oil recovered from wheat germ is not significantly affected by heating the extraction mixture during the extraction process.

The developments of free acids and peroxides in the oil during the storage period of wheat germ prior to extraction and during the hot extraction process were also investigated.

KEY-WORDS: Extraction - Hexane - Oil - Wheat germ.

\section{INTRODUCTION}

Wheat germ is commercially important chiefly because of its high content of tocopherols (0.3 - 0.5 $\%$ ). It contains about 8-14\% oil (average 10\%) and the crude oil is usually somewhat high in unsaponifiable matters (2-6\%). The tocopherols content (vitamin, E) of wheat germ oil is also extraordinary high. It is reported that one $\mathrm{Kg}$ oil contains about $1179 \mathrm{mg} \alpha$-tocopherols, $398 \mathrm{mg}$ $\beta$-tocopherols, $493 \mathrm{mg} \gamma$-tocopherols and $118 \mathrm{mg}$ $\delta$-tocopherols ${ }^{(1)}$.

Vitamin $E$ is the most stabilizer for cell membrane by protection against peroxidase cleavage of unsaturated fatty acids. The latter constitutes the integral part of phospholipids found in cell membrane. Vitamin E, by this unique action, preserves the integrity of all cells especially free cells with short life span e.g. red white blood cells and blood platelets. Also, vitamin E stops the oxidative interaction of LDL (s) whereby it prevents their precipitation on the arterial walls prohibiting atherosclerosis. It also enhances vitamin A utilization and acts as precursor for genital hormones ${ }^{(2)}$. In addition to tocopherols, the oil contains a considerable percentage of polyunsaturated fatty acids. The linoleic acid content ranges between 44 and $65 \%$ and the linolenic acid content ranges between 4 and $10 \%$. In addition to the above components, the oil contains some other natural agents which are proven to be valuable for immunity, integrity of blood vessels and restoration of cells.

Polyunsaturated fatty acids (PUFA) have an additive important role in the prevention of atherosclerosis by increasing the pathway of cholesterol to 'DL. The latter is of essential importance in the building of cells especially hepatocytes and corneocytes. PUFA serve also as precursor for biochemical compounds such as prostaglandins $^{(1-4)}$.

Relatively a huge quantity of wheat germ is produced annually as a by product of wheat milling industry in Egypt. In 2000, it was reported that about 120,000 tons wheat germ were produced from wheat milling ${ }^{(5)}$. This quantity can yield about 12,000 ton wheat germ oil annually at a total price of LE 1200 million. Unfortunately, the whole quantity of the germ produced is currently utilized in the production of animal fodder. It is advisable therefore that this by-product would be rather utilized for oil production.

This work was proposed to study the extraction process of wheat germ by hexane and to determine the optimum operating conditions for such process. 
Also, the effect of germ storage prior to extraction on the oil quality is also included in this study.

\section{EXPERIMENTAL}

Wheat germ used in this study was kindly supplied by North Cairo Flour Mills Company, Cairo and it was extracted using commercial hexane (b.r.62-68 ${ }^{\circ} \mathrm{C}$ ) ; a product of Alexandria Company for Petroleum, Alexandria.

The extraction was made at room temperature using different ratios of hexane to germ $(2,2.5,3,4$, 5 and $6 \mathrm{~m}^{3} /$ ton). The solvent and solid mixture was stirred mechanically at $250 \mathrm{rpm}$ for two hours, the miscella was then filtered and the solvent evaporated under vacuum. The extracted oil was then weighed and the oil recovery was estimated as a percentage of total oil that can be obtained by complete extraction in a soxhlet extractor. The procedures were made via two extraction methods; in a single and in a two successive steps. In the latter method, the solvent recovered from miscella evaporation in the first extraction stage was used to re-extract the residual oil in the extracted germ. In addition, the percentage oil recovery has been also determined when the extraction process is carried out at $50^{\circ} \mathrm{C}$ following same procedures. The extraction was made in a single step using $3 \mathrm{~m}^{3}$ hexane for each ton germ.

The effect of wheat germ storage prior to extraction on the development of free acids and peroxides was also studied over three weeks. The extracted samples were tested for their acid and peroxide content using the Official and Tentative Methods of Analysis ${ }^{(6)}$. The extraction of the stored germ samples was made by single stage batch extraction at room temperature and also by hot multistage soxhlet extraction. These two methods of extraction were applied as to see whether hot extraction of the germ will effect an increase in the

Table I

Effect of $L / S$ ratios on the percentage of oil recovered from wheat germ at about $25^{\circ} \mathrm{C}$

\begin{tabular}{cccc}
\hline & & \multicolumn{2}{c}{$\%$ Oil recovery } \\
\cline { 3 - 4 } Process & $\begin{array}{c}\mathbf{L}^{\mathbf{S}} \mathbf{S}^{*} \text { Ratio, } \\
\mathbf{M}^{3} \text { /ton }\end{array}$ & $\begin{array}{c}\text { Single stage } \\
\text { extraction, } \mathbf{M}_{1}\end{array}$ & $\begin{array}{c}\text { Double stages } \\
\text { extraction, } \\
\left(\mathbf{M}_{1}+\mathbf{M}_{2}\right)\end{array}$ \\
\hline 1 & 2 & 28.4 & 44.1 \\
2 & 2.5 & 50.5 & 76.4 \\
3 & 3 & 57.3 & 84.4 \\
4 & 4 & 76.2 & 92 \\
5 & 5 & 80.2 & 94 \\
6 & 6 & 83.1 & 98.7 \\
\hline
\end{tabular}

* L/S : The ratio between the volume of commercial hexane used as extracting solvent, $\mathrm{m}^{3}$ and the weight of solids (wheat germ), ton. level of free acids and peroxides in the oil. The extracted oil was tested for its fatty acid composition by gas-liquid chromatographic analysis of the methyl esters of wheat germ oil using Hewlett Packard Model 6890 Chromatograph. A capillary column 30.0 $\mathrm{m}$ length and 530nm inside diameter, packed with polyethylene glycol was used. The temperature was programmed from 100 to $240^{\circ} \mathrm{C}$ for 10 minutes, the injection temperature was $280^{\circ} \mathrm{C}$ and nitrogen at a flow rate of $15 \mathrm{ml} / \mathrm{min}$ was used as a carrier gas. The detector temperature was $280^{\circ} \mathrm{C}$ and the hydrogen and air flow rates were 30 and $300 \mathrm{ml} / \mathrm{min}$, respectively.

\section{RESULTS AND DISCUSSION}

The results of this work have been used to elucidate the effect of the extraction conditions on the oil yield and to throw a light on the effect of germ storage prior to extraction on the composition of extracted germ oil.

\subsection{Effect of the extraction conditions on the oil yield}

Process flow diagrams of wheat germ extraction at room temperature are given in Figures 1-6 which show the composition of input and output streams of each step. The results presented in these diagrams were used to predict the percentage of oil recovered in each case as affected by the number of stages and by the solvent-to-solid ratio, L/S. Also, they have been used to determine the data regarding the composition of liquid and solid phases at equilibrium.

\subsubsection{Percentage of oil recovered as affected by number of stages and LIS ratio:}

According to the results presented in Figures 1-6, the percentage of oil recovered using various solvent-to-solid ratios are calculated both for single

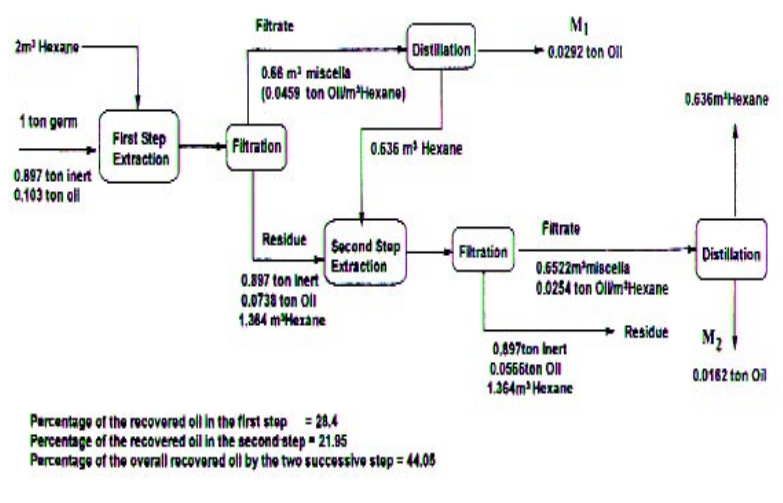

Figure 1

Process flow diagram of wheat germ extraction using liquid to solid ratio $\left(2: 1 \mathrm{~m}^{3} /\right.$ ton $)$ 


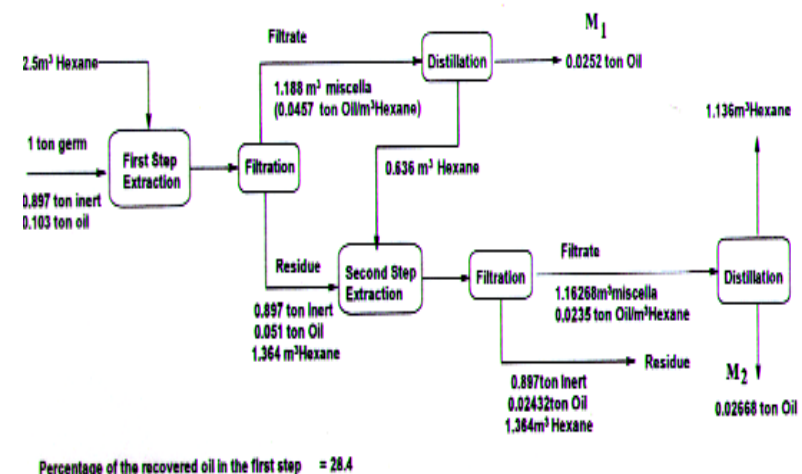

Petcentage of the rocovered oil in the lirst stap $=28.4$ Parcentage of the overall recovered oil by the two successive step $=4.05$

Figure 2

Process flow diagram of wheat germ extraction using liquid to solid ratio $\left(2.5: 1 \mathrm{~m}^{3} /\right.$ ton $)$

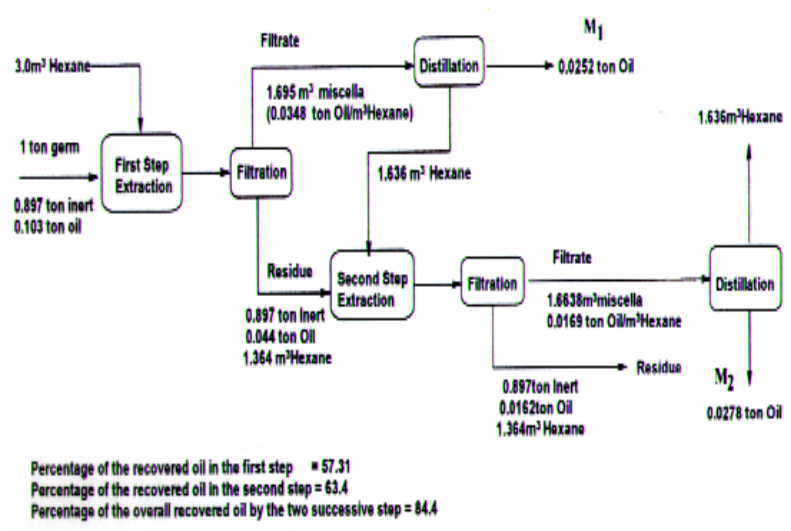

Figure 3

Process flow diagram of wheat germ extraction using liquid to solid ratio $\left(3: 1 \mathrm{~m}^{3} /\right.$ ton $)$

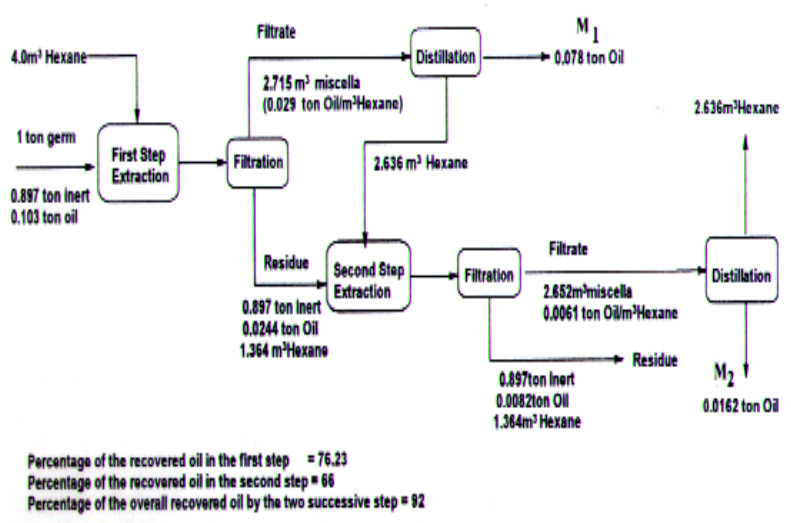

Figure 4

Process flow diagram of wheat germ extraction using liquid to solid ratio $\left(4: 1 \mathrm{~m}^{3} /\right.$ ton $)$

and double stages extraction (Table I and Figure 7). The percentage of oil recovery was calculated as $(\mathrm{w} / \mathrm{wt}) \times 100 \%$. $\mathrm{W}_{\mathrm{t}}$ refers to the weight of oil to be obtained by complete extraction of $100 \mathrm{~g}$ germ while

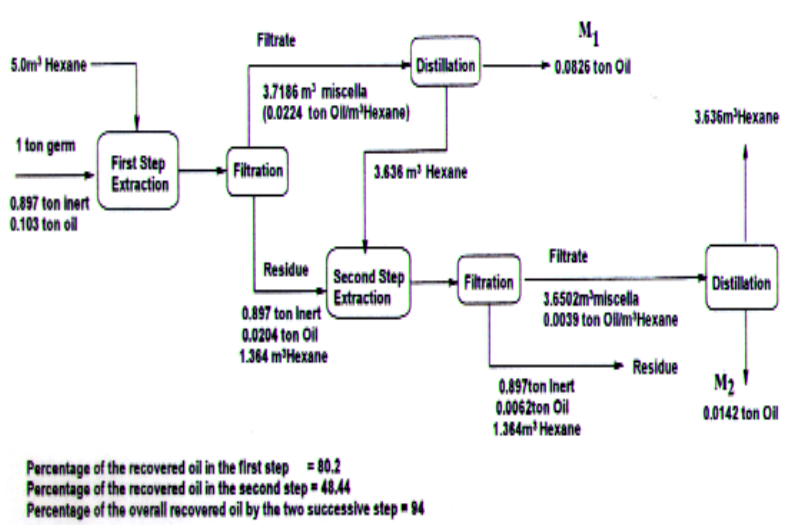

Figure 5

Process flow diagram of wheat germ extraction using liquid to solid ratio $\left(5: 1 \mathrm{~m}^{3} /\right.$ ton $)$

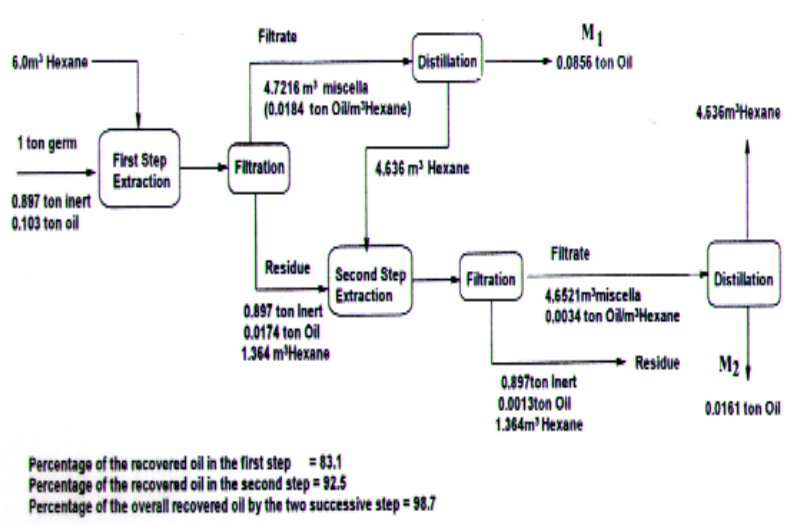

Figure 6

Process flow diagram of wheat germ extraction using liquid to solid ratio $\left(6: 1 \mathrm{~m}^{3} /\right.$ ton $)$

Table II

Composition of solid and liquid phases at equilibrium

\begin{tabular}{ccc||cc}
\hline \multicolumn{3}{c||}{ Solid phase, wt. Fraction } & \multicolumn{2}{c}{ Liquid phase, wt. fraction } \\
\hline Oil & Solvent & Solid & Oil & Solvent \\
\hline 0.031 & 0.58 & 0.389 & 0.044 & 0.956 \\
0.024 & 0.59 & 0.386 & 0.025 & 0.975 \\
0.022 & 0.59 & 0.388 & 0.044 & 0.956 \\
0.019 & 0.59 & 0.391 & 0.035 & 0.965 \\
0.011 & 0.596 & 0.393 & 0.029 & 0.971 \\
0.01 & 0.597 & 0.393 & 0.023 & 0.977 \\
0.009 & 0.598 & 0.393 & 0.022 & 0.978 \\
0.0076 & 0.599 & 0.393 & 0.018 & 0.982 \\
0.0073 & 0.598 & 0.3947 & 0.0167 & 0.9833 \\
0.0036 & 0.6 & 0.396 & 0.006 & 0.994 \\
0.0027 & 0.602 & 0.395 & 0.0039 & 0.9961 \\
0.0006 & 0.6029 & 0.3965 & 0.0035 & 0.9965 \\
\hline \multicolumn{4}{c}{} \\
\hline
\end{tabular}


w refers to the oil obtained by a single or double stages extraction. Wt has been determined using soxhlet extraction and found to be $10.3 \mathrm{~g} \mathrm{oil} / 100 \mathrm{~g}$ wheat germ. The results indicated that an acceptable oil recovery $(\geq 75 \%)$ has been achieved by single stage extraction using a solvent to solid ratio $\geq 4$. This ratio has been reduced to 2.5 when the extraction was made in two successive steps.

\subsubsection{Equilibrium data for wheat germ oil extraction by hexane:}

The compositions of the solid and liquid phases at equilibrium are listed in Table II. These data are graphically represented in a right angle triangle in Figure 8 . On basis of these equilibrium data, the number of extraction stages required to achieve a certain percentage of wheat germ oil recovery using solvent-to-germ ratio (L/S) between 2 and 6 has been determined ${ }^{(7)}$. Figure 9 shows the effect of the number of extraction stages as well as the ratio of

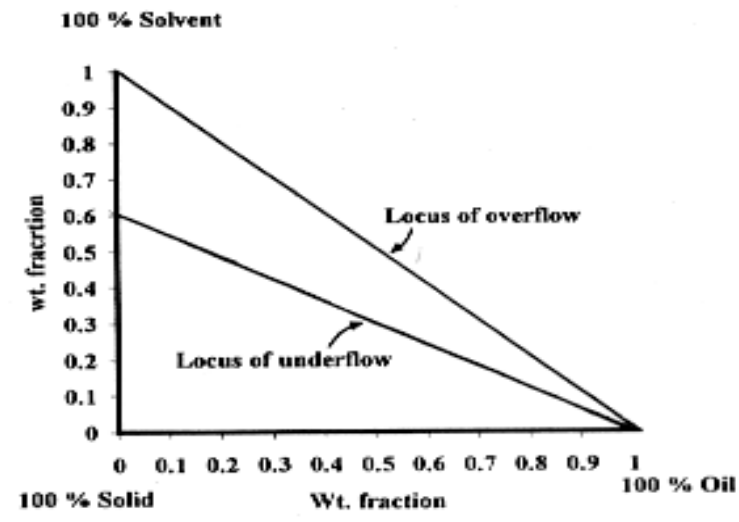

Figure 7

Representation of locus of overflow and underflow at equilibrium

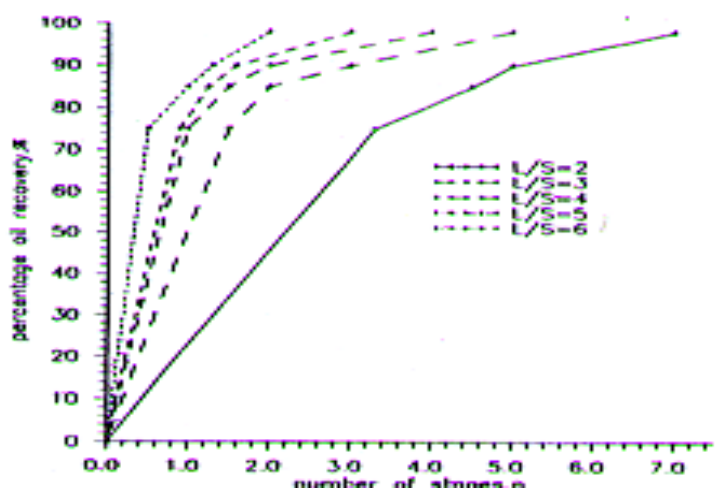

Figure 8

Effect of solvent-to-solid ratio (L/S) and the number of stages, $n$, on the percentage of oil to be recovered from wheat germ by solvent extraction
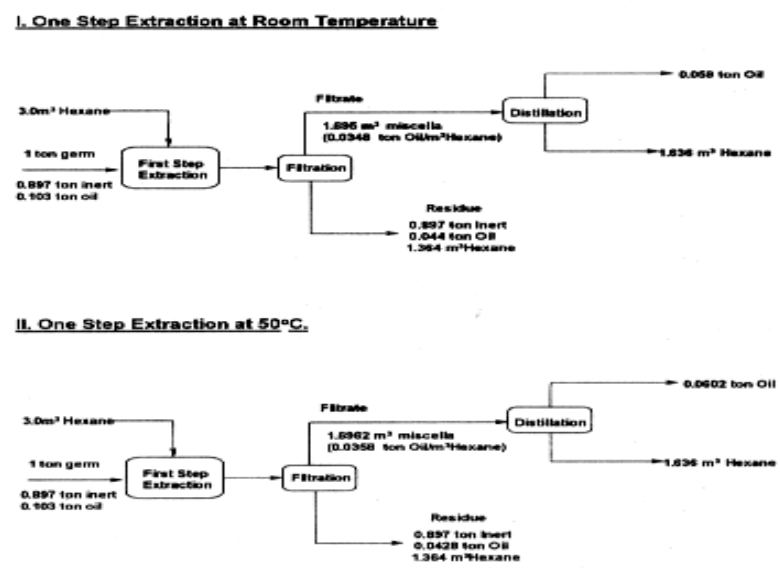

Figure 9

Comparison betwen the extraction of wheat germ a Hot $\left(50^{\circ} \mathrm{C}\right)$ and Cold $\left(25^{\circ} \mathrm{C}\right)$ in one step extraction using liquid to solid ratio $\left(3: 1 \mathrm{~m}^{3} /\right.$ ton $)$.

solvent-to-solid ratio, L/S on the percentage of Oil that can be recovered from wheat germ. It is clear that the effect of increasing the ratio L/S on increasing the oil recovered is more remarkable if the extraction is made in small number of extraction stages $(\leq 3)$.

The results of a single step extraction at $50^{\circ} \mathrm{C}$ is compared to that at room temperature $\left(\approx 25^{\circ} \mathrm{C}\right)$ in Table III and Figure 10. It can be stated that the percentage oil recovery achieved by extraction at room temperature $(57.3 \%)$ has not been significantly improved by increasing the extraction temperature to $50^{\circ} \mathrm{C}(\%$ recovery $=58.4 \%)$.

\subsection{Composition of wheat germ oil and the effect of germ storage prior to extraction on free acid and peroxide content}

The fatty acid distribution of wheat germ oil is listed in Table IV. The total of the polyunsaturated fatty acids, which are very important for the prevention of atherosclerosis and hence heart diseases, equals $66.43 \%$. These results are in agreement with those reported in the literatures which state that the fatty acids of wheat germ oil consist of palmitic acid, $11-16 \% ; \mathrm{C}_{20}-\mathrm{C}_{22}$ saturated, $0-1 \%$; Oleic, 8-30\% ; Linoleic 44-65\% and Linolenic, $4-10 \%(1,3,4,8,9)$.

Table III

Comparison between the results of single stage extraction of wheat germ using $\mathrm{L} / \mathrm{S}=3$ at room temperature $\left(\cong \mathrm{t} 25^{\circ} \mathrm{C}\right)$ and at $50^{\circ} \mathrm{C}$

\begin{tabular}{cc}
\hline Extraction temp. ${ }^{\circ} \mathrm{C}$ & \% Oil recovery \\
\hline$\simeq 25$ & 57.3 \\
50 & 58.4 \\
\hline
\end{tabular}


Table IV

Fatty acid composition of wheat germ oil

\begin{tabular}{cc}
\hline Fatty acid & Percentage, \% \\
\hline Palmitic acid & 16.72 \\
Oleic acid & 15.79 \\
Linoleic acid & 60.23 \\
Linolenic acid & 6.20 \\
Saturated acids, & 1.06 \\
$\left(\mathrm{C}_{20}-\mathrm{C}_{22}\right)$ & \\
\hline
\end{tabular}

The effect of wheat germ storage prior to extraction and that of the extraction temperature on the development of free acids as well as oil peroxides can be explained according to the results listed in Table V. These results show that oil oxidation during germ storage prior to extraction or during hot extraction is insignificant. However, the acid content increases from $3.86 \%$ to $6.1 \%$ during the storage of wheat germ for three weeks. It is also observed that heating of germ and hexane mixture during the extraction process slightly increases the free fatty acid content of the oil of about $1 \%$.

Table V

\begin{tabular}{|c|c|c|c|c|}
\hline \multirow{2}{*}{ Storage period, Days } & \multicolumn{2}{|c|}{ Peroxide value* } & \multicolumn{2}{|c|}{$\%$ Free acids ** } \\
\hline & Room temp. Extraction & Soxhlet Extraction & Room temp. Extraction & Soxhlet Extraction \\
\hline 0 & 0 & 0 & 3.86 & 4.98 \\
\hline 7 & 0 & 0.26 & 4.30 & 5.15 \\
\hline 14 & 0.27 & 0.32 & 5.00 & 5.50 \\
\hline 21 & 0.30 & 0.36 & 6.10 & 6.90 \\
\hline
\end{tabular}

* Peroxide value, meq. Oxygen / kg Oil

** \% Free acids, gm Oleic acid / 100gm Oil

\section{REFERENCES}

1. Swern, D. (1996). Bailey's Industrial Oil and Fats Products. Fifth edition, Vol.4.

2. Barnes, RJ. (1983). Wheat Germ Oil in Lipid in Cereal Technology. Edited by P.J. Barnes, Academic Press, NewYork.

3. Ibrahim, AAM; Abo Zaid, M.Ai and El-Mahdy, L.D. (1990). Studies on Crude wheat germ produced as a by-product of Milling industry. Analysis of Agriculture Science, Moshtohor 28, 1189-1200.

4. Tong W. and Lawrence A. J. (2001). Refining High-free fatty acid wheat germ oil. J. Am. Oil Chemist's Soc. 78, 71-76.

5. Statistics (2000). Department Agricultural Economic Institute, Ministry of Agriculture, Egypt.
6. Official and Tentative Methods of the American Oil Chemical Society (1980), $3^{\text {rd }}$ edn. Revised, Illinois.

7. Coulson, J.M. and Richards, J.F. (1985). Chemical Engineering, Volume 2, $4^{\text {th }}$ Edition.

8. Saker, A.; Fahmy, A.A. and Roushdi M. (1987). Evaluation of some chemical components in wheat, maize and rice germ oils. Grasas y Aceites 37, 134-136.

9. El-Makhzangi A. and El-Shawwaf AM. (1994). Effect of different solvents extraction on physiochemical properties of wheat germ oil. Mansura University of Agriculture Science 19, 1991-1999. 